\title{
Strategi penanganan Covid-19 melalui pemberdayaan UMKM dalam memproduksi APD di Kota Pekanbaru
}

\author{
Iwantono, Genny Gustina Sari*, \& Yohannes Firzal \\ Universitas Riau \\ * genny.gustina@lecturer.unri.ac.id
}

\begin{abstract}
Abstrak. Sejak Maret tahun 2020 penyebaran virus Corona telah melanda hamper seluruh belahan dunia. Jumlah korban semakin meningkat sementara vaksin penyembuhan belum juga ditemukan. Masyarakat yang gusar kemudian mulai berinisiatif menyelamatkan diri dan keluarga dengan membeli perangkat kesehatan seperti masker, handsanitizer hingga baju APD (Alat Pelindung Diri) atau yang lebih dikenal dengan istilah Baju Hazmat. Sayangnya, harga ketiga bahan tersebut melambung naik berkali-kali lipat, pihak-pihak nakal bermain dengan cara menumpuk barang lalu melemparnya kepasar dengan harga yang tidak wajar. Tidak hilang akal, masyarakat memutar otak memanfaatkan peluang bisnis baru di era Covid-19 ini termasuk membuat dan meracik sendiri handsanitizer, menjahit masker dan tentunya baju hazmat. Kelangkaan barang-barang di atas nyatanya mempengaruhi kinerja para tenaga medis. Pengabdian ini kami buat dalam rangka membantu pemberdayaan UMKM di Kota Pekanbaru mencoba membaca pasar dan memproduksi sendiri baju hazmatnya. Hasilnya dengan ketatnya persaingan dan kurangnya minat masyarakat menjahit baju Hazmat, tim pengabdian berhasil merangkul UMKM yang mengelola uaha konveksi sendiri meski skala kecil-kecilan.
\end{abstract}

Kata kunci: covid, hazmat, umkm, Pekanbaru

\begin{abstract}
Since March 2020 the spread of the Corona virus has hit almost all parts of the world. The number of victims is increasing while a cure has not yet been found. The angry community then began to take the initiative to save themselves and their families by buying medical devices such as masks, handsanitizers to APD (Personal Protective Equipment) clothes or better known as Hazmat shirts. Unfortunately, the price of these three materials has increased many times over, naughty parties play by piling up goods and then throwing them into the market at an unreasonable price. Do not lose their mind, people rack their brains to take advantage of new business opportunities in the Covid-19 era, including making and mixing their own handsanitizers, sewing masks and of course hazmat suits. The scarcity of these items actually affects the performance of medical personnel. This dedication is made in order to help empower UMKM in Pekanbaru City to try to read the market and produce their hazmat suits themselves. As a result, with the intense competition and the lack of public interest in sewing Hazmat clothes, the service team managed to embrace UMKM that manage their own convection, even though they are on a small scale.
\end{abstract}

Keywords: covid, hazmat, umkm, Pekanbaru

To cite this article: Iwantono., G. G. Sari., \& Y. Firzal. 2020. Startegi penanganan Covid-19 melalui pemberdayaan UMKM dalam memproduksi APD di Kota Pekanbaru. Unri Conference Series: Community Engagement 2: $537-540$. https://doi.org/10.31258/unricsce.2.537-540

(C) 2020 Authors

Peer-review under responsibility of the organizing committee of Seminar Nasional Pemberdayaan Masyarakat 2020 


\section{PENDAHULUAN}

Beberapa bulan belakangan merupakan waktu yang cukup sulit bagi masyarakat diseluruh belahan dunia disebabkan kehadiran sebuah wabah penyakit yang disebabkan oleh virus yang disebut dengan Corona. Virus Corona atau Severe Acute Respiratory Syndrome Coronavirus 2 (SARS-CoV-2) adalah virus jenis baru dari virus corona yang menular ke manusia dengan menyerang sistem pernapasan. Penyakit karena infeksi virus ini disebut Covid-19. Virus Corona bisa menyebabkan gangguan ringan pada sistem pernapasan, infeksi paruparu yang berat, hingga kematian.

Virus Corona ini telah menyebar diberbagai Negara di belahan dunia. Hingga pada minggu (19/7/20) data dari 216 negara terkonfirmasi orang yang positif mencapai 14.043.176 jiwa, dengan total yang meninggal ada 579.583 jiwa. Sedangkan di Indonesia sendiri pada Minggu (19/7/20) terkonfirmasi kasus positif yaitu 86.521 jiwa, dengan tingkat kesembuhan mencapai 45.401 jiwa dan pasien meninggal 4.143 jiwa. Oleh karena itu, berbagai upaya dilakukan untuk menekan angka penderita virus Corona baik pemerintah, tenaga medis dan tentunya masyarakat dengan melakukan seluruh kegiatan dirumah saja, dan mengikuti protokol kesehatan yang telah diarahkan apabila diharus bepergian ke luar rumah. Kota Pekanbaru merupakan Ibu Kota Provinsi Riau dengan tingkat penyebaran virus Corona yang cukup tinggi. Hingga Senin (20/7/20), melalui data yang di peroleh dari situs Riau Tanggap Corona Kota Pekanbaru sendiri memiliki ODP 56 orang yang masih dalam pemantauan, PDP 28 orang dan positif Corona 90 orang dengan 6 orang penderita telah meninggal dunia.

Kelangkaan ADP yang terjadi tidak hanya di Indonesia namun juga hamper diseluruh dunia mengakibatkan fenomena-fenomena baru muncul dilapangan. Tidak sedikit masyarakat yang berusaha dan berupya melindungi diri mereka dengan ADP yang mereka buat sendiri ditambah para tenaga medis terpaksa menggunakan ADP yang tidak sesuai prosedur untuk melindungi diri mereka menyebabkan mereka malah rentan terkne virus Covid-19 tersebut. Sesuai dengan Peraturan Menteri Kesehatan (Permenkes) pasal 6, ayat 1 nomor 27 tahun 2017 bahwa para tenaga medis perlu untuk dilindungi dengan penggunaan APD. APD tersebut terdiri dari penutup kepala (hoodie), pelindung wajah, pelindung mata (goggles), masker (respirator), sarung tangan, baju pelindung (gaun) dan sapatu boot. Baju pelindung yang dimaksud merupakan bagian penting dalam menghadapi pandemic COVID-19 ini dan dikenal dengan sebutan pakaian Hazardous Materials.

Pakaian Hazardous Materials atau dikenal juga dengan sebutan baju Hazmat atau pakaian dekontaminasi merupakan bagian perlengkapan perlindungan pribadi yang terdiri dari bahan yang impermeabel dan digunakan untuk proteksi melawan material berbahaya. Baju Hazmat umumnya dilengkapi dengan alat bantu pernapasan mandiri untuk memastikan yang menggunakannya mendapat pasokan udara untuk bernafas. Baju Hazmat juga dapat digunakan oleh pemadam kebakaran, teknisi medis darurat, paramedis, peneliti, petugas yang bereaksi atas kebocoran material berbahaya, tenaga ahli yang membersihkan daerah terkontaminasi, dan pekerja di lingkungan yang beracun. Sehingga kebutuhan Baju Hazmat dalam massa pandemic COVID-19 ini dirasakan semakin mendesak dan perlu segera untuk dipercepat pengadaannya di tengah sedang tinggi-tinggi kebutuhan akan jenis APD satu ini.

Fenomena di lapangan menunjukkan ketersediaan baju Hazmat di Kota Pekanbaru khususnya sangat minim. Petugas-petugas medis malah kewalahan melindungi diri mereka semaksimal mungkin meskipun tidak sesuai dengan prosedur yang baik dan benar. Untuk itulah dirasakan perlunya percepatan penyediaan baju Hazmat yang nantinya bisa di kontribusikan bagi para tenaga medis sebagai garda terdepan dalam penanganan pasien Covid-19 ini.

\section{METODE PENERAPAN}

Dalam rencana pengabdian pendampingan kepada UMKM untuk percepatan pengadaan baju Hazmat dalam rangka siaga bancana COVID-19 menggunakan beberapa metode dalam penerapannya: 1) Metode Ceramah. Metode ini dilakukan dengan cara satu arah dimana beberapa orang ditempatkan sebagai pembicara dan peserta menjadi audience. Ceramah dilakukan dengan media yang disesuaikan dengan situasi dan kondisi dimana ceramah dilaksanakan dengan tujuan agar komunikasi terbentuk dengan baik yang merupakan modal awal kelancaran pelaksanaan kegiatan ini, 2) Metode Diskusi tanya-jawab. Metode ini digunakan untuk menggali lebih jauh tentang keingintahuan UMKM dalam membahas materi pemanfaatan potensi usaha baju Hazmat. Diskusi akan mengembangkan kompetensi interaksi dan komunikasi efektif dalam menyatukan pendapat, 3) Metode Pendampingan. Pendampingan kepada UMKMt demi mewujudkan para UMKM dapat terus berkelanjutan dalam usaha konveksi melalui pembinaan secara berkesinambungan dan memberikan dampak yang lebih bermanfaat bagi para UMKM tersebut. Dan 4) Metode Simulasi. Metode ini digunakan untuk melatih para UMKM agar dapat menyesuaikan pada masalah yang sama. Simulasi sendiri adalah contoh buatan 
dari situasi yang sesunguhnya atau situasi yang dibayangkan. Simulasi dirancang dan dibuat serealistis mungkin sehingga peserta latihan dapat belajar dari tindakan-tindakan mereka tanpa mencemaskan untuk mengeluarkan biaya yang lebih.

\section{HASIL DAN KETERCAPAIAN SASARAN}

Mendistribusikan Hazmat hasil produksi sendiri dengan memanfaatkan UMKM yang sedang minim pesanan akibat pandemi covid-19 ini dibeberapa fasilitas medis yang telah disebutkan diatas. Dengan mendistribusikan baju hazmat tersebut akan membantu tenaga medis yang bekerja dalam pelayanan terhadap masyarakat akibat pandemi covid-19. Karena tenaga medis di berbagai fasilitas medis tersebut merupakan garda terdepan dalam penanganan pandemi ini.

\section{Rumah Sakit UNRI Pekanbaru}

Pada tahap pertama pendistribusian baju hazmat, Tim PKM memilih Rumah Pendidikan Universitas Riau sebagai lokasi pendistribusian Hazmat. Hal ini didasari oleh kebutuhan baju Hazmat yang cukup tinggi sementara di RS Pendidikan UNRI ketersediaan APD sangat terbatas. Pada kesempatan ini, Tim PKM mendistribusikan sebanyak 20 buah baju hazmat. Tim PKM juga berkolaborasi dengan tim lainnya yang menyediakan masker dan handsanitizer.

\section{Rumah Sakit Daerah Madani Pekanbaru}

Dukungan dari semua pihak kepada RSD Madani dalam hal sarana dan prasarana juga harus diiringi dengan kesiapan Sumber Daya Manusia (SDM) yang ada untuk penanganan pasien Covid-19. Sehingga nantinya jika ada pasien Covid-19 datang ke RSD Madani, maka tenaga kesehatan yag berperan dalam penanganan pasien Covid-19 sudah paham dan mengerti tugas yang akan dilakukannya terhadap pasien Covid-19 sesuai alur dan SOP yang sudah ditetapkan. Di RSD Madani tim mengalokasikan baju hazmat sebanyak 20 buah. Selain itu, itu tim juga mengadakan diskusi dan sharing dengan tenaga medis di RSD Madani terkait upaya untuk mencegah penambahan jumlah kasus Covid serta upaya-upaya untuk menanamkan kesadaran masyarakat akan pentingnya menerapkan protocol kesehatan selama masa pandemic ini berlangsung. Sebagai salah satu Rumah Sakit yang dijadikan sebagai tempat rujukan pasien Covid, para tim medis dan tenaga kesehatan di RSD Madani tentu harus meningkatkan kewaspadaan dan disiplin serta ketat menjalankan protocol kesehatan.

\section{Rumah Sakit Jiwa Tampan Pekanbaru}

Untuk pasien yang dirawat Inap Jiwa dan Napza tidak ada yang terjangkit Covid-19 Sebab RSJ Tampan sejak awal dinyatakan pandemi covid 19 sudah mengantisipasi dengan melakukan pembatasan kunjungan dengan melarang pasien dikunjungi oleh siapapun, serta masuk dan keluar pengunjung satu pintu dan dilaksanakan pemeriksaan scan suhu.Tak hanya itu, seluruh karyawan wajib memakai masker, physical distancing, dan selalu cuci tangan sesuai dengan protokol pencegahan covid-19. Pada tahap distrubusi kedua, tim menyerahkan baju Hazmat ke RSJ Tampan sebanyak 20 buah. Tingginya angka penyebaran covid tentunya menuntut para tim medis dan tenaga kesehatan untuk selalu siap sedia dalam menangani pasien positif Covid. Data di lapangan menunjukkan masih terbatasnya jumlah baju hazmat sementara jumlah pasien semakin meningkat di RSJ Tampan dirasa akan menghambat kinerja tim medis tersebut. Melalui pendistrubisan baju hazmat ini, tim berharap RSJ Tampan bisa meningkatkan kinerja dalam upaya penanganan pasien covid -19

\section{LAB Biomolekuler RSUD Arifin Ahmad}

Meskipun tidak menangani pasien yang terpapar covid secara langsung, namun Lab Biomolekuler di RSUD Arifin Ahmad menjadi tempat uji virus ini. Tentu saja tenaga laboran harus membekali dirinya dengan APD lengkap. Tim merasa perlu mendistribusikan baju Hazmat ke Lab Biomolekuler sebagai wujud kepedulian dan dukungan terhadap tenaga kesehatan yakni para laboran yang bekerja keras menganalisis sample masyarakat setiap harinya.

\section{Puskesmas Simpang Baru Panam}

Sebagai wilayah yang merupakan alur lintas antar kota dan provinsi puskesmas Simp Baru Panam perlu membekali dirinya dengan alat kesehatan yang memadai dalam upaya mereka membantu pemerintah menangani pasien covid-19. Puskesmas Simp Baru Panam yang menyediakan jasa Rapid test setiap hari harus dilengkapi dengan baju Hazmat. Untuk itu tim PKm mendistribusikan baju hazmat sebanyak 20 buah. Hal ini bertujuan aar tenaga kesehata di puskesmas juga data menjaga keselamatan dan kesehatan dirinya sehingga korban virus Covid tidak semakin bertambah 


\section{Puskesmas Poned Sidomulyo}

Pada tahap ini, tim mendistribusikan baju Hazmat sebanyak 15 buah yang nantinya akan digunakan oleh tenaga kesehatan di sana. Dalam kesemapatan ini, tim juga berdiskusi dengan kepala puskesmas terkait upaya puskesmas dalam mengedukasi masyarakat untuk lebih peka dan disiplin menjalankan protocol kesehatan selama masa pandemic. Sebagaimana diketahui bahwa masyarakat masih sulit menerima dan membiasakan diri untuk menerapkan pola hidup baru selama pandemic.

\section{Puskesmas Sentajo Raya Kuantan Singingi}

Tidak hanya didistribusikan di Kota Pekanbaru saja, tim pelaksana kegiatan pengabdian kepada masyarakat juga memberikan bantuan baju Hazmant ini hingga ke Kabipaten Kuantan Singingi. Dalam pelaksanaannya, Tim Satuan Tugas (Satgas) Covid-19 mendistribusikan menyerahkan sebanyak 30 hand sanitizer, 30 masker, dan 15 baju hazmat kepada Pusat Kesehatan Masyarakat (Puskesmas) Sentajo Raya Kecamatan Sentajo Raya, Kabupaten Kuantan Singingi.

\section{KESIMPULAN}

Kegiatan pengabdian masyarakat yang telah dilaksanakana dalam rangka peduli covid 19 telah berhasil dilaksanakan. Kebutuhan APD (Alat Pelindung Diri) di lapangan ternyata masih sangat tinggi. Melalui upaya pemberdayaan UMKM yang tersedia tim pengabdian berhasil mendistribusikan sebanyak 120 buah baju hazmat di kota Pekanbaru dan Taluk Kuantan. Dengan adanya kegiatan pendisribusian baju Hazmat ini dapat disimpulkan dua hal yakni bahwa kebutuhan yang tinggi tidak diikuti dengan ketersediaan barang dipasaran. Kalaupun baju hazmat ada beredar dipasaran nyatanya harganya melonjak sangat tinggi. Oleh karena itu melalui pendistrubusian ini diharapkan dapat membantu mengurangi kebutuhan tenaga kesehatan akan baju hazmat. Kedua, melalui pemberdayaan UMKM di Kota Pekanbaru, tim mencoba memberikan alternative bidang usaha baru bagi UMKM yang bergerak di bidang konveksi. Selain menyediakan dan memproduksi masker, baju hazmat juga bias dijadikan alternative lainnya. Dari kegiatan pengabdian ini dapat disimpulkan bahwa perlunya kerjasama dan control dari pemerintah dan masyarakat dalam meningkatkan kesadaran menjalankan protocol kesehatan termasuk penggunaan baju hazmat saat menangani pasien.

\section{DAFTAR PUSTAKA}

Cdc.gov. 2020. Infection Control Guidance for Healthcare Professionals about Coronavirus (COVID-19). Diakses pada 01 Mei 2020, dari https://www.cdc.gov/coronavirus/2019-ncov/hcp/infection-control.html

Fakhriyan Ardyanto. 2020. Berbagai Jenis Baju Hazmat agar Tidak Salah dalam Penggunaannya https://hot.liputan6.com/read/4215970/berbagai-jenis-baju-hazmat-agar-tidak-salah-dalam-penggunaannya

Kemenkes. 2014. Profil Kesehatan Kota Pekanbaru. Juli 20, 2020 www.pusdatin.kemkes.go.id

Nur Hidayah Perwitasari. 2020. IDI Imbau Baju Hazmat dari Masyarakat Sebaiknya Sesuai Standar WHO. https://tirto.id/idi-imbau-baju-hazmat-dari-masyarakat-sebaiknya-sesuai-standar-who-eNcT

Rsjwa Tampan. 2020. Profil RSJ Tampan dan Perkembangan Data Pasien Covid-19. Juli 20, 2020. https://rsjiwatampan.riau.go.id/50815-2/

RSUD Arifin Achmad. 2020. Peresmian Laboratorium Biomolekuler RSUD Arifin Achmad Provinsi Riau. Juli 20, 2020. http://rsudarifinachmad.riau.go.id/gubernur-riau-resmikan-laboratorium-biomolekuler-rsud-arifin-achmadprovinsi-riau/

Sorta, Tobing .2020. Panduan Standar APD untuk Tenaga Medis yang Menangani Pandemi Corona. https://katadata.co.id/berita/2020/04/07/panduanstandar-apd-untuk-tenaga-medis-yang-menangani-pandemicorona

Yusuf Dwi Putra. 2020. Mengenal Alat Pelindung Diri (Hazmat Suit) untuk Petugas Kesehatan https://blogs.insanmedika.co.id/mengenal-alat- pelindung-diri-hazmat-suit/ 